Stebljuk Svitlana,

Candidate of Pedagogic Sciences, Mukachevo Cooperative Trade and Economic College

Mukachevo, Ukraine

E-mail:svetastebluk@gmail.com

\title{
IMPLEMENTATION OF INNOVATIVE METHODS AS AN EDUCATIONAL PERSPECTIVE FOR THE TRAINING OF COMPETENT SPECIALISTS
}

\begin{abstract}
The article proposes modern approaches to the formation of professional competence of future entrepreneurs. The sequence of application of separate innovative methods of training, efficiency of which has been proved in the course of professional activity is revealed.

Keywords: future specialists in entrepreneurship, competence approach, professional competence, innovative teaching methods, techniques.

The training of future specialists in entrepreneurship, trade and exchange activities in Ukraine is gaining new meaning. Laws of Ukraine "On Higher Education” [1], “On Education” [2], "On Professional Education Movement" [3] determine the competence approach to the professionalization of knowledge as a priority.

"The competence approach means that the student needs to have an idea of contemporary problems in society, to understand "how the world is constructed", which physical, economic, social and other law it uses, to understand the existence of different social roles and to be able to act in these roles. Based on this, we can draw conclusions about which competencies are needed and should be formed by a specialist, namely: communicative; general cultural; value-semantic; educational and cognitive; informational and social-activity; personal development competence. Teachers should lay down a principle to the student that it is necessary for him to grow, develop, be able to solve problems, communicate with other people and, most importantly, be happy" $[4,58]$.

Today, scientific researches on the formation of professional competence of specialists in different areas of training in the system of degree education

have been activated. We have analyzed a number of authors' works: A. Aleksyuk, O. Gluzman, A. Kasich, M. Nagach, O. Ovcharuk, O. Pometun, O. Romanovskyi, O. Savchenko, N. Trishkina, T. Furman and others. N. Trishkina observes, therefore, that "the task at the forefront is now to provide a training for a new type of worker. Their most important quality should be professional flexibility and mobility, that is, the ability to quickly re-qualify or change the profession if necessary ... The entrepreneur falls into the conditions when, on the one hand, his professional and technical knowledge must ensure the quality and performance of professional activities, and on the other hand, the commercial qualification should help him in finding places to apply knowledge and skills in the market" [5, 194-195].

Innovative teaching methods contribute to the professional formation of future professionals in entrepreneurship, trade and exchange activities.

Innovation in education envisages the improvement of traditional and introduction of non-standard methods. In the process of research, new technologies were introduced, that were aimed at the formation of a competitive person with appropriate moral and ethical qualities.
\end{abstract}


Here is a description of application of some innovative teaching methods in the process of teaching professional disciplines.

Simulation method. It involves solving a situation close to quasi-professional activity. Students are offered a problem that needs to be solved.

For example, the problem-situation "Economic behavior of the consumer". Two shoppers who have the same wages and the same amount of money in their wallets are entering store "Rainbow". While observing the prices of the goods folded on the showcase, the first of them says: "Too expensive". The second replies: "A completely affordable price." What, in your opinion, may be caused by such different assessments?

Method "International Glossary". This method is aimed at formation of a communicative competence based on the knowledge of the state Ukrainian language and one of the foreign languages. Objective: to translate the terms using the bilingual UkrainianEnglish dictionary. Students make a table-shaped dictionary.

Table 1.- Glossary to the topic "Advertisement"

\begin{tabular}{|l|c|}
\hline Українська мова & Реклама \\
\hline Ринок рекламних послуг & \\
\hline Рекламні агентства & \\
\hline Аизайн реклами & Аd \\
\hline Телереклама & \\
\hline Зовнішня реклама & \\
\hline Вітринні наклейки & \\
\hline Рекламний вплив & \\
\hline Брендинг & \\
\hline Сейлз промоушн & \\
\hline Паблік рілейшнз & \\
\hline Аирект-маркетинг & \\
\hline
\end{tabular}

Copywriting method. Based on the given text, student composes economical essay that should be more emotional, shorter, and motivating. For example, the content of the text:

In the process of opening your own business, one must take into account the location factor, which plays a crucial role in some areas of business. The problem of the territorial location of the enterprise is decided on the basis of: the cost of the supply of finished products, semi-finished products; costs of sales of finished goods; the specifics of the technological process.

Defining the location of an enterprise is the choice of several alternative solutions under the conditions of uncertainty, which should be selected by matching the calculations on which the best option is determined. The exact location of the enterprise

English

Advertisement

Market of advertisement services

Advertising agencies

Design of advertisement

Television advertising

External advertisement

Showcase stickers

Advertisement influence

Branding

Sale promotion

Public Relations

Direct marketing

(closer to the consumer or to the supplier of raw materials) is conditioned by the technological process.

The method of the PRES formula. It is aimed at formation of skills of professional communication through the study, defending their own positions in the discussion process. The terms of the discussion: thesis - justification - proof - conclusion.

Examples of abstracts.

1. Informing customers about retail prices on the enterprises of retail trade is carried out by using labels of prices (price tags) or the indication of prices of the samples of the goods.

2 . In trading on private exchanges members and of the people performing the role of financial intermediaries take part. Modern exchanges abroad are mostly closed, as exchange trading is high risk and requires high professionalism. 
3. On macrologistical level logistics channels and logistics chains are the connections between subsystems of macrologistical systems. Depending on the kind macrologistics system channels and the distribution chain have different structure. In logistics systems with direct connections there are only distribution channels. They do not contain any wholesale intermediary firms. In flexible layered systems and logistics chains of such intermediaries exist. When you select a channel and the distribution chain the choice of the form of distribution of transit or storage, the choice of a particular distributor, the carrier, insurer, freight forwarder, banker is conducted.

The method of gradual familiarization with the case. It involves the presentation conducted by the teacher about the material abstracts, a list of keywords; students continue to use gadgets to provide information, after which an exchange of views and information sources are discussed. The teacher generalizes the students' work and gives additional information.

Method of work by "Keller Plan" [6]. Its essence lies in the self-regulated mastery of learning material with the involvement of proctor students as consultants. Proctors are assistants from among the most successful fellow students, perhaps from among the senior students, graduate students; they conduct individual counseling, provide a permanent feedback "teacher-student".

"The purpose plan". It involves an exchange of thoughts, during which students can not argue with each other. The work is carried out on small sheets of paper with a clear explanation of the thoughts. This method is used to analyze the situation that the group is currently dealing with. Algorithm of work: a certain problem is selected; the participants are divided into groups in which they formulate answers to questions related to this problem in 4 positions: the real state of affairs, as it should be, why in reality it is exactly like this, and not, as it should be and solutions.
Task. Identify the ratings of individual suppliers of sausage products, compare the values obtained to determine the best partner, formulate conclusions.

The students carry out the calculations of the rating providers, compare the results, identify the best partner. If the supplier is below the permissible value, the supply contract on the decision can be terminated even under the initiation of sanctions.

On Economics of the trade enterprise lessons it would be appropriate to use different methods of critical thinking development: work with key words, with various types of questions, graphic conversion of educational material, including by drafting socalled "mind maps". The application of this technology develops students' attentiveness, the ability to consider different points of view, critical of the level of their knowledge.

The development of critical thinking skills allows you to find your own educational route when studying individual topics, solving individual issues. For example, "Economic warm-up". Target: before the beginning of the proverb, quess the ending and explain its meaning.

The results of our scientific research about the implementation of innovative teaching methods showed that students notice:

- that their motivation to study professional disciplines increases;

- improvement of their quality of knowledge;

- skills of socialization of the personality;

- development of economic and managerial competences;

- that skills of research work are formed;

- a sense of responsibility, team collaboration, leadership, honesty, and so on are brought up.

Thus, we have proposed some innovative teaching methods tested in the process of training future specialists in entrepreneurship, trade and stock activities. They were aimed at the development of professional competences, creativity, critical thinking and the formation of the qualities of a modern European person. 


\section{References:}

1. Law of Ukraine "On Higher Education" of 01.07.2014 No. 156-VII: URL:http://zakon4.rada.gov.ua/ laws/show/1556-18

2. The Law of Ukraine "On Education" dated September 5, 2017.- No.-2145.- VIII. URL:https://zakon. rada.gov.ua/laws/show/2145-19

3. Law of Ukraine "On Professional Movement of Education". URL: http://w1.c1.rada.gov.ua/pls/zweb2/ webproc4_1?pf3511=65599

4. Panfilov Yu. I., Furmanets B. I. Competency approach in education: experience, problems, perspectives. The theory and practice of social systems management: philosophy, psychology, pedagogy, sociology. 2017.- No. 3.- P. 55-67.

5. Trishkina N. I. Modern approaches are to forming of professional jurisdictions of specialists of trade and economic type. Bulletin of the University of Dnipropetrovsk named after Alfred Nobel. Series "Pedagogy and Psychology". Pedagogical sciences, 2015.- No. 1(9).- P. 193-197.

6. Prikhodko D. P., Zorkin R. Yu. Modern foreign experience of activating the educational process in high school. Scientific-practical conference of KhNU I. Kozhedub, June 30, 2017.- P. 123-131. 